\title{
Che Guevara: América Latina, o despertar de um continente ${ }^{1}$
}

\section{Minha Boca Narra o que meus Olhos lhe Contaram}

"Arranhando um verso de Sábato" (Guevara, 2005) com o eterno prazer que sempre sentira pela poesia, fazendo-a sua inveterada companheira, Ernesto Guevara de la Serna começa sua primeira jornada de aventureiro teimoso em janeiro de 1950 para conhecer sua Argentina natal, mas desta vez pelo norte, que o aproxima de uma realidade conhecida apenas de soslaio e que não havia tido a oportunidade de captar mais cuidadosamente.

Quem sabe desde que imaginara uma viagem pela América Latina, tenha se sentido atraído por esta primeira iniciativa de dívida não quitada e ao mesmo tempo tão indispensável. Poucas páginas sobre essa experiência foram conservadas, mas bastam as que se conhecem para adentrarmos em seu mundo tão íntimo, carregado de devaneio e filosofia, disposto a aproximar-se de forma tão tangível da realidade para avançar, a partir desse momento, numa busca incessante de sua verdade, dessa verdade que o levará infinitamente ao longo de sua existência, a tratar de tocar o sentido real do povo, do que confessara só ser possível conhecer

\footnotetext{
${ }^{1}$ Originalmente foi publicado como prólogo ao livro América Latina, despertar de un continente, La Habana, Cuba, 2016. Traduzido do original por Raphael Lana Seabra, docente do Departamento de Estudos LatinoAmericanos da Universidade de Brasília (ELA-UnB), Revisão de Joana Salém Vasconcelos, doutoranda em História Econômica pela Universidade de São Paulo (USP).

${ }^{2}$ Coordenadora Acadêmica do Centro de Estudos Che Guevara e Membro Titular da Academia de Ciências de Cuba.

${ }^{3}$ Referência a Ernesto Sábato (1911-2011), intelectual e escritor argentino autor de três romances "O Túnel" de 1948, "Sobre Heróis e Tumbas" de 1961 e "Abaddon, o Exterminador" de 1974. Ao fim da ditadura civil-militar argentina presidiu a Comissão Nacional de Desaparecidos. Desde jovem Che o leu e o incorporou em seu Cuaderno Filosófico e depois do triunfo da Revolução Cubana trocaram correspondências.
} 
ao com ele desenvolver intimidade, ainda quando não estivesse em condições de emitir juízos mais concretos.

Milhares de quilômetros caminhados por terras áridas, belas ou não, lhe serviram para se dar conta de uma constante que o seguiria por toda a vida, sua visão do atraso ao que é submetida a imensa maioria da população, apenas pelo fato de não ocupar uma posição privilegiada na sociedade e estar condenada à pobreza e à vulnerabilidade.

Apenas um ano o separava de sua primeira viagem pelo continente, que sem dúvidas deixaria marcas permanentes e que seria lembrada toda vez que pensasse, voluntária ou involuntariamente, na América. Nesse breve lapso, sua consciência social avançava a passos gigantescos, tratando de esquadrinhar ao seu redor e além dele mesmo, o quanto era possível conhecer para alcançar um caminho que satisfizesse seus interesses e desejos. Alistado como enfermeiro em barcos que o levam por terras caribenhas ou como sanitarista na zona do porto de Buenos Aires, percorreu vivências que, mesmo não plasmadas em escritos, o nutriram e serviram para que se decidisse a empreender caminhos e buscas mais profundas, pelo fato de tê-las experimentado.

Desta vez, a empresa é maior e muito arriscada, percorrer de moto uma parte considerável da América. Não estaria sozinho, seria acompanhado por um parceiro à sua altura, seu amigo Alberto Granado, capaz de compartilhar suas quimeras e perseguir propósitos similares.

Até onde chegou, esta viagem teve contornos imperecíveis, o que pode ser apreciado através do costume tão iniludível em Ernesto de escrever tudo o que seus olhos lhe contaram. Relatos que, sem tal pretensão, descrevem e descobrem, num estilo muito próprio - precursor do cronista que sempre foi -, realidades e verdades que o levam pela mão por terras desconhecidas, alusivas e sugestivas e que o farão mudar mais do que imaginava.

“Talvez, dos dez rostos possíveis só vi um (...). Minha boca narra o que meus olhos lhe contaram" (Guevara, 2004, p. 26), Chile, Peru, Colômbia, Venezuela, essências de um mesmo fim, que o conduzem a penetrar verdades intuídas, mas não corroboradas. Não importa que confessasse suas limitações para contar o que desvendou. O que chega ao leitor é suficiente para que se entendam as buscas e propósitos e se possa afirmar com objetividade e precisão que emitiu juízos certeiros.

Desde o Chile uma constante, a denúncia diante da injustiça: primeiro naquilo que conhecia mais detalhadamente, a Medicina, depois com os mineiros e, num nível mais alto, 
com uma família de mineiros comunistas, com quem se sentiu "mais irmanado que nunca". Frente tanta injustiça, o essencial da mudança é decidido, motivado por uma gestão ausente e a exploração impiedosa a que os humildes eram submetidos, com um acréscimo surpreendente: nestas primeiras apreciações de índole política, aparece a necessidade de abalar "o desagradável amigo ianque", caso se deseje verdadeiramente alcançar um nacionalismo soberano e independente.

O Peru possui um significado superior, porque somado a seus juízos anteriores, adentra num problema até então para ele desconhecido: o tema indígena. O impacto da barbárie do conquistador frente à riqueza monumental de uma cultura cerceada, a mais poderosa expressão da civilização indígena, o leva primeiro a apreciar diretamente a imensidão e vastidão de sua arquitetura e cultura, para na medida certa penetrar na cruel submissão de uma conquista intolerante, que só busca a colonização de homens em prol de seus interesses metropolitanos e feudais, parasitários e transculturadores.

No dia de seu aniversário, após seis meses de iniciado o trajeto, no relato intitulado "O dia de São Guevara" (Guevara, 2004, p. 108), em uma invocação irônica do peronismo, podem ser percebidos os diversos modos como já é capaz de qualificar e sentir a América Latina unida, como única forma de integração pela evocação bolivariana.

Caracas, "a cidade da eterna primavera" (Guevara, 2004, p. 138), é o final da longa luta que o conduz a outro problema ainda mais desconhecido, "a visão do negro na vida comum com o branco" (ibidem), como outra face da colonização racista e deformante, história cruel de rivalidades e enfrentamentos que integram as raízes coloniais até o século XIX e que persistem até nossos dias na forma de preconceitos e do colonialismo mental.

O final ou o princípio (difícil discernir quando o autor não utiliza datas para explicar o que sente e expressa) o "Comentário marginal" sintetiza e sugere, sem ordem cronológica, porque as narrativas foram elaboradas depois de transcorrida a viagem e, portanto, entrelaçadas por um fim imperceptível, de alguém que não demonstra, mas sim acentua algo que era ou estava se convertendo numa força maior, pelo momento espiritual, etéreo, próprio do confesso e irônico "eclético dissertador de doutrinas e psicanalista de dogmas" (Guevara, 2004, p. 143).

No entanto, faltava às precisões e às disjuntivas, a reiteração de elementos tais como o povo, a conquista do poder, o humanismo - princípio recorrente e permanente em toda sua trajetória e obra -, e o latino-americanismo só alcançáveis por meio de uma revolução, que 
vão adquirindo outras dimensões que transcendem suas explicações iniciais e o levam a reafirmar convicções íntimas, pensar em se lançar na luta junto ao povo, mesmo quando a morte se aproxime e chegue "em perfeita demonstração de ódio e combate" (Guevara, 2004).b

Passariam anos e muitos acontecimentos em sua vida para que frases similares fossem escritas com igual sentido; foi preciso que, em primeiro lugar, lançasse um segundo olhar para nossa América, Outra Vez - título que daria a seu Diário -, com maiores propósitos, mas com idênticos significados.

Em julho de 1953, depois de concluir seus estudos universitários, em companhia de outro amigo da juventude, Carlos Calica Ferrer, começa o outro trajeto, primeiro pela Bolívia, com o objetivo de conhecer um processo revolucionário que havia iniciado sob a condução do Movimento Nacionalista Revolucionário (MNR) em 1952. Seu interesse fundamental era, basicamente, porque desconhecia o verdadeiro significado de uma revolução, o comportamento e a participação das massas dentro da mesma, com exceção do movimento peronista de seu país, sobre o qual levantava muitas questões.

A revolução boliviana não o seduziu o suficiente para que lançasse sua âncora, porque naquele momento, vislumbrou com clareza a debilidade política e ideológica de seus dirigentes para enfrentar um movimento de transformação radical nas estruturas de dominação, assim como previu o processo de esgotamento ao não se tornarem efetivas as metas propostas ao início. Mesmo que de forma espontânea, ele pode constatar a força potencial do povo, encabeçada no caso boliviano pelo mineiro ancestralmente explorado.

É lógico que não escapou à observação penetrante do jovem Ernesto Guevara a pressão que o governo dos Estados Unidos exercia para dobrar o processo revolucionário boliviano, envolvido como estava em desenhar sua nova política da Guerra Fria e conduzir os bolivianos a uma situação sem saída, que ao final provocaria o abandono de suas bandeiras e a incerteza em seus propósitos nacionalistas.

Decide continuar viagem sem imaginar que com esta decisão encaminharia seus passos a um futuro inevitável. No Equador, conversando com um grupo de amigos sobre sua experiência boliviana, o pedem para continuar a viagem para a América Central, com o propósito de conhecer o processo revolucionário guatemalteco, que tantas expectativas causava entre os dirigentes políticos e intelectuais mais avançados do continente.

Nessas circunstâncias, escreve uma carta à sua família em que emite um juízo revelador a respeito do que ocorria em seu interior e que ajuda a compreender o 
comportamento de ações futuras, "na Guatemala me aperfeiçoarei e conseguirei o que me falta para ser um autêntico revolucionário" (Guevara, 1987, p. 215).

Em sua visão da época, o pan-americanismo e o imperialismo são pares que se encontram. Alguns, conscientes ou não, agem como meros instrumentos desse imperialismo, que representa a acumulação de capitais, exportação, concentração monopolista e exploração dos mercados produtores de matérias-primas. Quando os interesses demandam, surgem, solapadas ou explícitas, as exigências imperiais para obrigar a alistá-los nas fileiras de uma democracia ao uso e medida dos Estados Unidos.

É por isso que na vida do "aspirante a revolucionário", Ernesto Guevara, um ponto de virada tanto intelectual como ideológico em sua evolução encontra-se na Guatemala, , porque mesmo ao compreender as limitações conceituais e programáticas daquele processo, 0 considerou como uma "autêntica revolução", para a qual valia a pena se arriscar.

É um período multiplicador, no qual se misturam a experiência com a necessidade de aprofundar os estudos, sobretudo, filosóficos, que com tanto afinco havia começado a realizar nas primeiras épocas da juventude e que o ajudariam a esclarecer o empreendimento de novos caminhos.

A Guatemala foi sua incipiente escola revolucionária e também sua frustração, derrotada a revolução em junho de 1954. "Despedaçamento de outro sonho da América", assim definiu a desonrosa conjura do Departamento de Estado, da CIA e dos governos títeres da América Central contra um governo que apenas pretendeu transformar sua economia medieval, ditando uma moderada lei de Reforma Agrária, mas, sobretudo, pelo simples fato de cometer a ousadia de expropriar da United Fruit Company as terras que "lhe pertenciam" (Guevara, 1987, p. 235).

Essas pretensões de um governo legítimo, eleito pelo povo, bastaram para que a CIA colocasse em marcha uma operação internacional, na qual a Guatemala foi convertida em nação dominada pelo "comunismo internacional" e, por consequência, um perigo evidente para paz e a segurança hemisférica. Antes do ano da implementação prática da Reforma Agrária, prepararam o isolamento diplomático, promoveram a subversão interna, foram criados atritos artificiais entre seus vizinhos e, por último, foi preparada a força de choque de mercenários treinados pela CIA que invadiriam o país a partir de Honduras.

Para Ernesto, a frustração da derrota, longe de desanimá-lo, lhe serviu para se convencer ainda mais de que a via escolhida era a decisiva. É interessante sintetizar algumas 
de suas observações emitidas em cartas e em seu Diário de viagem: a primeira e a principal delas sobre o papel dos Estados Unidos na derrubada do governo de Jacobo Árbenz, fato que o torna mais anti-ianqui, mais anti-imperialista. Mais tarde, vem a afirmação consciente de que a única via para conquistar o império da justiça na América era a revolução., Por último, a convicção de seu pertencimento à América e integrada em uma só luta.

A partir da Guatemala de Árbenz, Che contata um grupo de revolucionários cubanos que havia atacado o Quartel Moncada e eram exilados políticos. Através deles, conhece os objetivos do Movimento 26 de Julho e de seu líder, Fidel Castro, que nessa época estava preso nas cadeias cubanas, pela condução do levante armado de 26 de julho de 1953, na então província de Oriente.

Mais tarde, no México, Che se encontra de novo com aqueles cubanos e em junho de 1955 conhece Fidel, recém libertado da prisão. Desse encontro, deixa registrado em seu Diário algumas impressões: "Foi um acontecimento político ter conhecido Fidel Castro, o revolucionário cubano, rapaz jovem e inteligente, muito seguro de si mesmo e de extraordinária audácia; creio que simpatizamos mutuamente" (Guevara, 2000, p.92).

Encontro determinante, que vincularia para sempre Ernesto Guevara, conhecido a partir de então como Che, à Revolução Cubana, uma das facetas mais enriquecedoras de sua vida e que o permitiria alcançar, posteriormente, suas aspirações da juventude.

Paralelamente a esse encontro decisivo no México, ele não apenas se deteve a analisar as causas diretas que possibilitaram a derrota da revolução guatemalteca, mas também, como consequência, as lições da história vivida lhe serviram para ampliar e depurar sua consciência política e traçar com mais precisão seu destino futuro, o que estava indissoluvelmente unido ao papel preponderante do homem, como antecedente direto do que, posteriormente, constituiria a essência e o centro de seu pensamento humanista.

Perfila com maior profundidade as razões pelas quais o latino-americanismo e o imperialismo marcham em eterna contradição. Desta vez suas análises são reforçadas com estudos mais integrais do marxismo, especialmente de Karl Marx e da Economia Política, ao considerá-los como referenciais teóricos imprescindíveis para entender os males da América e poder alcançar uma solução final através do socialismo, mesmo que ainda não estivesse suficientemente consciente do que implicava essa assertiva. Por tudo isso, o encontro com Fidel é premonitório, pois lhe amplia a convicção de luta que o leva à participação direta na liberação de Cuba, cumprindo com aquilo que considerava definitivo: “América será o teatro 
de minhas aventuras com caráter muito mais importante que eu haveria acreditado" (Guevara, 1987, p. 206).

Cuba seria a ponte necessária para poder adquirir a experiência única e irrepetível de fazer parte da vanguarda de um povo que apostou na independência de seu país por meio da via que considerava fundamental: a luta armada.

Ele resume essas ideias quando, em plena luta nas terras cubanas, é entrevistado por seu compatriota, o jornalista Jorge Ricardo Masetti: "Estou aqui, simplesmente, porque considero que a única forma de libertar a América de ditadores é derrubando-os. Ajudando com sua queda de qualquer forma. E quanto mais direta melhor”. E mais adiante, quando lhe perguntam se sua intervenção nos assuntos internos de uma pátria que não era a sua poderia ser tomada como uma intromissão, acrescenta: "Em primeiro lugar, eu considero minha pátria não apenas a Argentina, senão toda a América. Tenho precursores tão gloriosos como o de Martí e é precisamente em sua terra onde me atenho a sua doutrina" (Guevara, 1959 p. 37).

\section{Para o Lutador que Persegue Quimeras}

É um novo ciclo na vida do Che, no qual a experiência adquirida acrescenta elementos próprios a seu comportamento, convertendo a luta revolucionária cubana em seu primeiro degrau nas aspirações na construção de uma nova América. Ao latino-americanismo, esboçado anteriormente, incorpora razões suficientes para compreender até onde poder avançar e é na guerra onde encontra suas primeiras respostas de integração.

Na luta revolucionária em Cuba não só mediu forças para vencer os obstáculos próprios de uma contenda militar, mas também acima de tudo encontrou a via propícia para sua total identificação com um processo revolucionário que, como o cubano, se propunha efetuar profundas mudanças estruturais.

A extensão dessas convicções o faz afirmar consequentemente que Cuba representa um novo passo no desenvolvimento da luta dos povos da América para alcançar sua libertação definitiva. Esse despertar da América, após o triunfo da Revolução Cubana, dia $1^{\circ}$ de janeiro de 1959, reforça seus critérios sobre as rotas que deviam utilizar os povos latino-americanos.

Foram distintas e complexas as tarefas assumidas como dirigente em Cuba, as quais se tornaram exemplo e referência obrigatória em sua permanente ascensão como expressão plena de sua formação marxista e revolucionária. Combinou com singular capacidade a teoria para 
enriquecer com sentido criador o que na prática o processo revolucionário estava levando a cabo para poder alcançar propósitos mais elevados, contribuindo com seus aportes nas esferas do econômico e do político ao desenvolvimento da transição socialista na ilha.

No entanto, apesar da complexidade da empresa, nos anos em que permaneceu em Cuba, Che não desistiu do empenho de buscar unir e reforçar as frentes de luta possíveis dentro do continente, ao levar em consideração as similaridades e objetivos comuns que se conjugavam, essencialmente os mesmos problemas sociopolíticos e o inimigo comum.

É uma etapa na qual se reúne e conversa com um número considerável de revolucionários latino-americanos, que além de desejar conhecer diretamente a experiência de uma revolução, estavam precisando de vínculos afins que reforçassem suas convicções sobre o caráter inadiável de começar a luta que os levaria a alcançar a soberania de seus respectivos países. Dedicou longas jornadas a discutir sobre futuras táticas e estratégias, ao considerá-las como os princípios fundamentais para poder lograr o triunfo revolucionário.

Desde 1959, em discursos, entrevistas e trabalhos são assinaladas profundas reflexões com amplo espectro, nas quais analisa temas cruciais nos campos econômico, político e social, até chegar a um primeiro exame realmente amplo sobre a unidade tri-continental, como uma espécie de preâmbulo do que seriam posteriormente suas teses terceiro-mundistas.

Alguns desses postulados foram escritos depois do percurso efetuado em 1959 pelos países que conformavam o Pacto de Bandung, antecedente do futuro Movimento dos Países não-Alinhados:

"Cuba foi convidada à nova conferência dos povos afro-asiáticos. Um país americano exporá
as verdades e a dor da América diante do reverente conclave dos irmãos afro-asiáticos. Não irá
por casualidade, irá como resultado da convergência histórica de todos os povos oprimidos
nesta hora de libertação. Irá para dizer que é certo que Cuba existe e que Fidel Castro é um
homem, um herói popular. (...) Desde a nova perspectiva de meu mirante (...) tenho que
responder a todas as centenas de milhões de afro-asiáticos que marcham em direção à liberdade
nestes tempos atômicos, que sim, como nunca: sou outro irmão desta parte do mundo que
espera com ansiedade infinita o momento de consolidar um bloco que destrua, de uma vez por
todas, a presença anacrônica da dominação colonial" (Guevara, 1970, p. 387).

Essa permanente lição de Cuba o convence de quão indispensável seria para América Latina "conseguir sua coesão política para defender sua posição no campo internacional" e, inclusive, lhe permite refletir sobre um tema que, mais tarde, analisará em circunstâncias mais complexas, mas que colocado em 1959, diz muito sobre o que havia avançado na busca dos caminhos mais eficientes para alcançar a plena libertação do continente. 
Este tema sobre o qual se adianta com admirável precisão é o referido Fundo Monetário Internacional, sobre o qual ressalta:

"se é um elemento de libertação para a América Latina, eu acredito que teria de ter sido demonstrando, e até agora não conheço nenhuma demonstração de que tenha ocorrido tal coisa. O FMI cumpre funções totalmente diferentes: a de assegurar precisamente o controle de toda a América, por parte dos capitais que estão localizados fora da América” (Guevara, 2017a).

A partir de sua experiência guerrilheira em Sierra Maestra e da abrangência do projeto de libertação cubano, começou a ser desenhado um projeto de transformação para a América Latina em que se sustentava a necessidade de reformas econômicas e sociais profundas, encabeçada pela Reforma Agrária, ao ser considerada como a primeira medida de todo governo revolucionário na América que pretendesse a conquista de seus direitos plenos, através da estreita comunhão que deveria ser estabelecida entre um verdadeiro Exército do povo - a vanguarda indiscutível na obtenção da plena libertação -, que unido às massas constituiriam os verdadeiros portadores da real independência, obrigados a enfrentar, em primeira instância, as forças imperialistas e as falsas democracias que detém o poder.

Por volta de 1961, o então presidente Kennedy propõe, frente ao desenvolvimento inquestionável de Cuba e de seu exemplo persistente, um programa denominado Aliança para o Progresso, com o propósito de entregar fundos aos países latino-americanos para seu desenvolvimento e progresso. No entanto, tal programa apesar de sua aparente proposta de mudança nas relações hemisféricas, não deixa de ser uma expressão depurada da hegemonia econômica e política que historicamente mantiveram na região.

Com o fracasso da agressão mercenária contra Cuba, em abril desse mesmo ano, os Estados Unidos aceleram a implementação do programa da Aliança, apoiado num plano de ajuda exterior, mas condicionado à aplicação de determinadas medidas internas em cada país, que garantiriam a subordinação aos interesses do vizinho do norte. Coloca-se em marca a política de ordem para a América Latina que asseguraria ao governo estadunidense sua segurança interna e que, por sua vez, propiciaria o caminho para a eliminação consensual da Revolução Cubana, tema para o qual não contavam com suficiente respaldo.

Cuba era um espinho cravado contra Washington, não porque havia violado algum acordo continental, mas sim porque havia sido capaz de resolver os problemas que ainda não haviam sido solucionados em muitos países da América Latina. Era nesse terreno que deveriam competir, pois com o triunfo de Fidel Castro, seu exemplo seria mais perigoso que 
qualquer ação de agressão direta. Esse e não outro era o verdadeiro sentido da Aliança para o Progresso exposta pelo presidente Kennedy.

Na conferência de Punta del Este, onde seria discutida a Aliança, Ernesto Che Guevara participou como chefe da delegação cubana. Participou em esgotadoras seções de trabalho e em discursos nos quais não apenas detalhou a postura de Cuba, mas também, onde analisou as enormes limitações e diferenças que separavam o verdadeiro caminho do desenvolvimento que deveriam perseguir os países da região em contraste com as propostas batidas e obsoletas, mesmo que com novas roupagens, apresentadas pelos Estados Unidos.

$\mathrm{Na}$ voz de Che e contra prognósticos mal intencionados, Cuba ofereceu o apoio para alcançar uma ação conjunta construtiva, apesar de suas suspeitas sobre as verdadeiras intenções e alcances da Aliança, e propõe sua colaboração para que em Punta del Este se assentem as bases de um plano efetivamente progressista, em benefício de muitos e não de alguns.

Che define o caráter político da Conferência e de sua relação com a economia. Mesmo assim, estabelece um conjunto de parâmetros válidos para qualquer política que pretendesse alcançar uma verdadeira integração econômica, ao ter em consideração o perigo que representavam, para aquele momento, os monopólios internacionais e suas pretensões de dirigir totalmente os processos de comércio dentro das associações de livre comércio.

São propostas medidas e planos racionais de desenvolvimento, a coordenação de assistência técnica e financeira de todos os países industrializados, a tentativa de salvaguardar os interesses dos países mais débeis e a proibição de atos de agressão econômica de uns membros contra os outros, acompanhada de uma garantia de proteção aos empresários latinoamericanos contra a concorrência monopolista e conseguir a redução dos impostos norteamericanos aos produtos da região e dos investimentos diretos sem exigências políticas.

Logicamente as conclusões alcançadas na Conferência ignoraram os argumentos apresentados por Cuba, uma vez que centraram a atenção na análise e na realidade política econômica seguida pelos Estados Unidos, a qual respondeu historicamente às suas necessidades, sem levar em conta as demandas da economia da América Latina e que invariavelmente derivaram numa política incongruente e na falta de desenvolvimento regional sustentado.

Vários outros temas foram tratados pelo Che no decorrer da Conferência e que depois ele retoma em diversos trabalhos mais detidamente, de acordo com as circunstâncias e 
contextos determinados. Este é o caso das transformações que deveriam ser produzidas de forma total nas estruturas das relações de produção para alcançar o verdadeiro progresso. Para o Che a única alternativa possível encontrava-se na liberação do comércio, uma plena política econômica independente conjugada à uma política externa também independente ou, do contrário, assumir a luta aberta, enfrentando diretamente os monopólios estrangeiros.

Esta e não outra tem sido a história do século XX americano, ideia que foi sustentada pelo Che levando em consideração as circunstâncias de seu tempo e demarcadas as abismais diferenças entre Norte e Sul, em que correspondeu à América Latina o papel de base tática da penetração econômica imperialista, que no caso particular dos norte-americanos, a converte no quintal para a exportação de seus capitais. Além de ser o foco de influência ideológico mais próximo, e por fim, alvo favorito para buscar destruir as tradições e as culturas regionais e locais, já deformadas pelo parasitismo feudal. Che defendia, com insistente apelo, que o principal efeito dessa penetração havia sido devastador. Caracterizava-se por um atraso absoluto da economia, causa real do subdesenvolvimento e da dependência neocolonial, no qual nem sua própria elite havia sido capaz de governar. Muito pelo contrário, com sua atitude entreguista haviam agudizado ainda mais os polos antagônicos entre a acumulação extrema de riquezas de uma minoria e o extremo empobrecimento da maioria.

Até então, Che estava absolutamente convencido de que a única alternativa real nesses momentos históricos era enfrentar o inimigo por meio da luta armada. Em diversos trabalhos e discursos, de 1962 em diante, como "Tática e estratégia da revolução latino-americana”, "A influência da Revolução Cubana na América Latina", aponta incisivamente não só a substituir as raízes de todos os males e fenômenos sociais de caráter permanente que subsistem no continente, mas, sobretudo, a advertir que num mundo economicamente distorcido pela ação imperial, a única solução era a luta político-militar através de uma tática e estratégia global corretas por parte de sua verdadeira vanguarda, que permitiria o triunfo político das massas até conquistar a vitória continental.

Fazer a guerra necessária, como postulou Martí, significava aproveitar o contexto histórico em que era possível debilitar as bases econômicas do imperialismo, destruir a oligarquia reacionária e tratar de polarizar a luta. Como adverte Che, parafraseando o discurso de Fidel pronunciado nos Estados Unidos em 1960, a única forma para que "cesse a filosofia da guerra, é que cesse a filosofia da desapropriação" (Guevara, 1970, p. 541). 


\section{Que a Liberdade seja Conquistada em cada Canto da América}

Como se pode constatar, para o Che seu projeto de transformação social vai sendo perfilado gradualmente desde 1960 com componentes que constituem o fundamento essencial de atuações posteriores. À práxis revolucionária imediata, produto de uma experiência concreta, como é a Revolução Cubana, ele vai incorporando uma perspectiva revolucionária geral e não circunscrita aos interesses de Cuba. Nesta perspectiva estão enunciadas suas principais teses terceiro-mundistas, as quais se convertem num instrumento viável para o movimento revolucionário e para alcançar, como objetivo supremo, a plena emancipação da humanidade.

É uma fase que coloca a prova suas condições como homem de ação que se impôs iniciar uma revolução anti-imperialista, cujos antecedentes remontam a sua experiência guatemalteca de 1954. Esta perspectiva é delimitada numa primeira etapa da revolução latinoamericana, na qual Cuba emerge como a vanguarda, mas sem ignorar as tradições de luta do continente, cujas raízes entroncam com Bolívar, desde que em 1815 na Carta de Jamaica, promulgou a unidade das Américas.

Para o Che, essa unidade continental era o substrato de sua estratégia de luta como a única via, primeiro, de libertação nacional, para depois ser seguida da obtenção da libertação definitiva, por considerar a América o continente mais avançado do Terceiro Mundo e, por sua vez, o mais contraditório.

Por isso é explicável a obrigação sentida por Che, antes de empreender o caminho da ação armada no Congo e na Bolívia, de escrever textos imprescindíveis para compreender o alcance de suas decisões. Em todos ressalta o caráter iniludível da revolução e a decisão de empreender iniciativas que agudizassem as contradições sociais para abrir caminho à participação popular, por serem portadoras, em última instância, da transformação necessária, se distanciando do voluntarismo e sectarismo.. Apontava que o provável êxito da luta radicava numa acertada organização, encabeçada por uma vanguarda revolucionária, tomando em conta a experiência adquirida no processo revolucionário cubano, em que se conscientizou sobre o inimigo principal e das forças revolucionárias com que se deveria contar, além de avaliar, com conhecimento pleno, as contradições principais e secundárias que regem tanto no plano nacional como no internacional e das tarefas imprescindíveis a empreender para 
acentuá-las ou apagá-las, com o propósito de conduzir o processo a sua finalidade: a tomada do poder e sua transição ao socialismo.

A condução desse processo exigiria a formação de organizações político-militares coordenadas entre si e encarregadas de dirigir o conjunto da luta. Mas a partir da própria luta, como requisito essencial de toda vanguarda que na verdade se preze de ser o destacamento mais desenvolvido. Em tais exigências, colocava-se em evidência a sequela das posições assumidas por décadas dentro do movimento comunista continental e que, posteriormente, o próprio Che padeceria na Bolívia com a atitude assumida pelo secretário geral deste partido, quando se distanciavam das realidades concretas da América Latina e buscavam soluções dentro de uma estratégia orientada a promover a revolução democrático-burguesa.

O expoente máximo de seu pensamento e conceitualização, naquele momento, constitui, sem dúvidas, o mundialmente conhecido ensaio "Mensagem à Tricontinental", publicado quando se encontrava em plena luta em terras bolivianas e no qual resume sua estratégia revolucionária mundial. Esta mensagem de libertação sintetiza suas teses terceiromundistas ao enfatizar que frente um sistema mundial imperialista a única fórmula para exterminá-lo é combatê-lo num enfrentamento mundial, por um lado, através da eliminação das bases de sustentação e, por outro, em união com a participação plena dos povos. À América, "continente esquecido", atribui uma tarefa primordial, "a de criação do segundo ou terceiro Vietnã", como o caminho para solucionar os problemas do continente. Luta que considerava longa e cuja finalidade estratégica seria a destruição do imperialismo.

Neste processo, além das realidades imperantes na América Latina, é imprescindível tomar em consideração o debate de temas cruciais nos quais Che participou e onde pontuou suas posições, com o fim de direcionar a luta pela rota que eliminaria as incongruências e a contradição do esquema criado pela divisão do mundo em duas grandes esferas de confluência: capitalismo versus socialismo. As teses terceiro-mundistas do Che enfocavam-se no centro dessa polêmica e buscavam mudar essa polaridade a partir de posições de esquerda.

Ele estabeleceu sem ponderações e com total agudeza, a posição de princípio que deveriam adotar os países socialistas, definindo a cota de sacrifício que lhes cabia entregar caso desejassem contribuir ao desenvolvimento dos países dependentes. Advertiu claramente que não poderiam permanecer indiferentes, nem no terreno econômico nem no enfrentamento armado, porque tanto uma derrota como uma vitória pertenceria a todos. Este alerta implicava inequivocamente que o socialismo tinha que voltar seus olhos de forma radical para o 
Terceiro Mundo se estivesse verdadeiramente comprometido com a estratégia revolucionária mundial.

A compreensão cabal da determinação de Che a respeito de sua incorporação à luta, partindo das observações assinaladas, foi resumida no discurso que pronunciou no Segundo Seminário Econômico de Solidariedade Afro-Asiática, em Argel: "Não existem fronteiras nesta luta de morte, não podemos permanecer indiferentes frente ao que ocorre em qualquer parte do mundo, uma vitória de qualquer país sobre a derrota de uma nação qualquer é uma derrota para todos. O exercício do internacionalismo proletário não é só um dever dos povos que luta por assegurar um futuro melhor, também é uma necessidade inevitável. Se o inimigo imperialista, norte-americano ou qualquer outro, desenvolve sua ação contra os povos subdesenvolvidos e os países socialistas, uma lógica elementar determina a necessidade de uma aliança dos povos subdesenvolvidos e dos países socialistas, se não houver nenhum outro fator de união, o inimigo comum deveria constituí-lo" (Guevara, 1970, p. 572).

Esta certeza, desde sua ótica, era o ponto de partida para esboçar a aliança entre os povos subdesenvolvidos que luta por se libertar do imperialismo e os países socialistas, conscientes de que os Estados Unidos interviriam contra qualquer surto revolucionário que surgisse, como efetivamente aconteceu em todos estes anos.

Com o advento dos surtos revolucionários na América Latina são desenhados e postos em prática, com a condução direta dos estadunidenses, sistemas autoritários com denominadores comuns, que atuavam paralelamente à militarização da sociedade ou converteram a si mesmos em regimes militares de fato. Esta doutrina político-militar encontrava justificativa para sua implementação na luta guerrilheira iniciada nos anos sessenta e a urgência de implantar condições de estabilidade social.

Está claro que essa política não era em absoluto nova, pois tinha como antecedente a implementação da Doutrina de Segurança Nacional em inícios dos anos cinquenta dentro do contexto da Guerra Fria, criada para conter o comunismo internacional e sua extensão para a América. É imprescindível recordar a Guatemala de Árbenz onde se colocam em prática medidas que caracterizariam a intervenção estadunidense, entendendo que seus interesses encontravam-se em perigo. A tais posturas agrega, em 1959, o advento da Revolução Cubana que contribuiu para o reforço dessas políticas e de outras ainda mais violentas.

A partir desses momentos, a linguagem e fatos se tornaram mais incisivos e alcançaram uma dimensão regional, com a fundamentação de que se devia combater o 
comunismo em qualquer lugar que se apresentasse, para evitar que a partir de Cuba seguissem proliferando os surtos insurrecionais. Advogava-se por uma resposta eficaz na forma de ajuda material e espiritual às comunidades "afetadas" e ao fortalecimento dos exércitos latinoamericanos, que deveriam estar preparados para lutar contra a subversão interna.

A essência final da doutrina ficou inscrita em incontáveis páginas sangrentas ao longo de décadas no continente, buscando ocultar a insatisfação popular, cada vez mais empobrecida e a tensão social e política que tudo isso gera. Definitivamente a "segurança nacional" serviria para justificar a repressão em torno daquilo que poderia provocar desajustes, sem estabelecer diferenças entre subversão, crítica, oposição política, guerrilha, terrorismo ou guerra, todos entendidos como manifestações de um único fenômeno: a guerra revolucionária, que como tal deveria ser exterminada a qualquer preço e onde o aparato militar seria o instrumento para ser empregado para assumir a repressão como o ingrediente indispensável, encarregado de sustentar a dominação.

Para o Che, que havia encontrado desde muito jovem na América o laboratório idôneo para medir seu crescimento humano e ideológico desde o movimento revolucionário boliviano de 1952, a Guatemala de Árbenz, passando pela Cuba de Fidel e culminando nos feitos da Bolívia em 1956, como síntese desse processo, sua teoria sobre a luta armada significou uma ruptura com o pensamento imperante na esquerda latino-americana da época, expressada pelos partidos comunistas que promoviam, essencialmente, a transição pacífica ao socialismo, princípio não excluído por Che, mas condicionado a um forte movimento de luta como inescapável antecedente.

De modo irrevogável, ele se deu a tarefa de forjar um foco guerrilheiro na Bolívia, de buscar conquistar seu crescimento, para depois, a partir daí, controlar uma porção importante do território e convertê-lo em formador de outras guerrilhas surgidas em outros países latinoamericanos. Considerava que sua presença deveria lhe dar uma projeção continental, ao ganhar um espaço próprio no combate e converter a guerrilha numa alternativa concreta diante do poder estabelecido.

No decorrer dessa etapa, a primeira parte de sua evolução ocorreu com triunfos indiscutíveis apesar dos muitos detratores que de antemão condenavam a ação, alguns dos quais se pronunciaram abertamente desde os próprios países socialistas, condenando a guerrilha e o sangue derramado e o que se derramaria caso continuasse "3 ou 4 Vietnãs", como aponta Che em seu Diário de campanha. 
No entanto, no próprio Diário Che escreve para a posteridade, em franca oposição a expressões desse tipo, com seu estilo peculiar e sintético o significado do 26 de julho: "rebelião contra as oligarquias e contra os dogmas revolucionários" (Guevara, 1970a), elementos que constituem os fatores determinantes que impedem a verdadeira ascensão da revolução e aos que, irrevogavelmente, tem de enfrentar, contrário a qualquer "doutrina de gabinete" ().

Poderia se argumentar bastante sobre a ressonância histórica das páginas de heroísmo escritas por Che e seus companheiros na Bolívia, porém, suas próprias memórias da juventude expressão mais que qualquer conclusão, o verdadeiro sentido da coerência e entrega que caracterizaram toda sua vida com uma dimensão essencialmente humanista e ética: "realmente creio ter chegado a compreendê-la [a América] e me sinto americano com um caráter distintivo de qualquer outro povo da terra" (Guevara, 1987, p. 213).

\section{Conquistar o Porvir}

Com ressonâncias da história, "como um hino revolucionário destinado a se eternizar nos lábios dos combatentes da América" (Guevara, 1970, p.540), assim Che vislumbrava o futuro do continente, caso fosse capaz de varrer as travas e os esquemas que haviam impedido alcançar sua libertação definitiva. Não era a utopia e nem o sonho o que imperava em suas aspirações, mas sim a análise da situação econômica, política e social prevalecente por séculos, o que o levava a se lançar à batalha pela plena independência.

Ele sabia que o uso brutal da força se implantaria ferozmente para impedir qualquer movimento revolucionário, sem que acarretassem retrocessos. Mas de igual maneira, também advertiu que momento histórico era propício para enfrentar essa força cega e de não realizá-lo nesse contexto, o custo político acarretaria retrocessos inesperados.

Em todos estes anos, muitas foram as fórmulas ensaiadas pela reação inimiga, apesar da repressão impiedosa dos sessenta e setenta até transições que oscilaram entre uma aparente democratização e uma violência sutil. Este panorama palpável a partir da desaparição do mundo socialista e a implementação do neoliberalismo o e da globalização, onde os esquemas de dominação se tornam mais absolutos.

Para a América Latina o saldo tem sido extremamente grave, do temor ao dogma totalitário passou-se à liberdade irrestrita do mercado e, como resultado, à do mundo da 
injustiça globalizada, traduzido na perda das liberdades políticas toda vez que esta deriva das "liberdades econômicas", em que a função do Estado é minimizada em garantidora da plena vigência desse mercado em todos os planos da sociedade.

Dadas suas limitações, o regime política traz aparelhado o abandono da soberania nacional e, ao contrário do defendido, perdem-se cada vez mais as liberdades democráticas e se recrudesce de novo o emprego da violência e do autoritarismo como mecanismos idôneos para frear qualquer surto de inconformidade, agredindo tanto as liberdades individuais como as coletivas e, a consequente reiterada violação dos direitos humanos, apesar do discurso oficial de "respeito aos mesmos".

Para alguns países da América Latina, a situação atual é o negativo de uma radiografia de qualquer prognóstico crítico que feito antecipadamente, mesmo que não mediassem critérios tão incisivos e verdadeiros como os usados por Che. Nem os mais conservadores puderam prever os estragos de um mercado selvagem como o existente e de suas respectivas insuficiências para atender a pavorosa miséria e desigualdades de um continente de 400 milhões, onde mais da metade encontra-se afundada na pobreza e centenas na indigência extrema.

Ao final do século passado o drama havia chegado ao fundo, incluindo os próprios governantes que placidamente aceitaram a política imperante da globalização, cujo resultado conformou a existência de um grupo de países da região em crise, com uma ampla corrupção governamental e, portanto, um imenso e conhecido descontentamento popular.

As céticas perguntas sobre qual seria o sinal imperante no novo século multiplicaramse, depois do fracasso das políticas postas em prática como a Área de Livre Comércio paras Américas (ALCA), com uma roupagem aparentemente diferente, mas que só trouxe terríveis consequências sociais, maior degradação laboral, maior privatização, destruição do meio ambiente, restrições aos direitos democráticos, maior pobreza e desigualdade, condensando num governo continental de fato, comandado pelos Estados Unidos e que satisfaz todos os seus interesses hegemônicos. Às vezes, sentiu-se as vozes de países que dignamente buscaram reverter o drama e buscado promover uma nova ordem mundial que seja mais racional e justa. Para América Latina, continente esquecido e subjugado por séculos, esta é uma demanda imperiosa, toda vez que uma parte de sua população é submetida ao extremo, está se demandando uma América humanista, com equidade e justiça social e uma plena soberania, 
expressadas em governos que proponham projetos libertadores como alternativas viáveis diante dos poderes ilimitados de sempre.

A adoção de verdadeiras transformações como parte do compromisso histórico da região com a construção, entre todos, de projetos nacionais e regionais de desenvolvimento sustentável, nos quais se encontrem representados os interesses dos povos dentro dos possíveis espaços alcançados, apesar de sua aparente fragmentação, evidencia a luta por novas formas que propiciem a mudança como principal compromisso e uma dívida histórica com o bicentenário da independência do continente com nossos povos subjugados. O caminho é extremamente difícil e perigoso, mas não impossível, apesar dos reveses pelos quais atravessamos na atualidade, como o caso do Brasil assediado e humilhado, o cerco extremo à revolução venezuelana e dos 60 anos da Revolução cubana no poder, são exemplos palpáveis da necessidade da unidade diante da cada vez mais irracional força do poder hegemônico e ditatorial dos Estados Unidos. É imperioso direcionar as lutas defendendo tudo o que nos une como fatores indiscutíveis de nossa identidade e soberania.

Neste gérmen incipiente, portador das mudanças futuras, Che encontra um espaço com a memória histórica viva, para recordar que esse desafio, capaz de resgatar toda uma história de rebeldia acumulada e de múltiplas experiências políticas é o único caminho a seguir, ainda que o mundo não seja o mesmo e as soluções adquiram novas formas, se verdadeiramente se está disposto a "conquistar o porvir".

\section{Referências}

ARIET GARCÍA, María del Carmen. El pensamiento político del Che. Ocean Sur: La Habana, 2007.

Resonancias de futuro. Para leer al Che. Ocean Sur: La Habana, 2018.

GUEVARA LYNCH, Ernesto. Aquí va um soldado de América. Buenos Aires: Editorial Planeta, 1987.

GUEVARA, Ernesto Che. Los que luchan y los que lloran. La Habana: Editorial Madiedo, 1959.

. "América desde el balcón afroasiático" in Che Guevara. Obras (1957-1967), T. 2. La Habana: Casa de las Américas, 1970. 
"Diario de Bolivia" in Che Guevara. Obras (1957-1967), T. 1. La Habana: Casa de las Américas, 1970a.

. Che Guevara presente. Ocean Sur: La Habana, 2005.

. América Latina, despertar de un continente. Ocean Sur: La Habana, 2017. . "Entrevista para Radio Rivadavia de Argentina, 3-11-59" in Che en la Revolución

Cubana, T. 2. La Habana: Editorial José Martí, 2017a.

. Notas de viaje. Diario en motocicleta. Ocean Sur: La Habana, 2004

Otra vez. Ocean Su: La Habana, 2007.

\title{
Che Guevara: América Latina, o despertar de um continente
}

\begin{abstract}
Resumo
O presente trabalho trata do jovem Ernesto Guevara e de um conjunto de pressupostos pesquisados pela autora sobre as inquietudes e percursos que realizou na América Latina. Depois,- transformado em Che - seguiu propósitos e decisões maiores que o levariam a uma dimensão profunda de luta pela verdadeira soberania e independência do continente. A partir do devir histórico de Che, o artigo contribui para entender seus propósitos desde que iniciou suas primeiras viagens pelas regiões agrestes ou não, todas com resultados análogos: a formação de um compromisso imparável para com a humanidade latino-americana e sua plena libertação.
\end{abstract}

Palavras-Chave: Ernesto Che Guevara - América Latina - Libertação - Soberania

\section{Che Guevara: América Latina, el despertar de un continente}

\section{Resumen}

El presente trabajo forma parte de un conjunto de presupuestos investigadas por la autora con el objetivo de apropiarse de una mirada profunda sobre las inquietudes y búsquedas que realizara, primero, el joven Ernesto Guevara sobre el contexto y el entorno de la América Latina de sus años juveniles, para seguirle, después convertido en Che-, propósitos y decisiones mayores que lo llevarían a una dimensión superior marcada por su inquebrantable determinación de luchar por la verdadera soberanía e independencia del continente. Esta mirada vista desde su devenir histórico, contribuye a una comprensión más acabada para entender los propósitos que se propuso alcanzar desde que iniciara sus primeros recorridos por regiones, agrestes unas y otras sugestivas, pero todas con idénticos resultados: un compromiso indetenible para con el hombre latinoamericano y su liberación plena.

Palabras clave: Ernesto Che Guevara - América Latina - Liberación - Soberanía

\section{Che Guevara: Latin America, the awakening of a continent}

\begin{abstract}
The present work is part of a set of presuppositions investigated by the author with the objective of appropriating a deep look at the concerns and searches that first Ernesto Guevara will make on the context and environment of Latin America of his years youth, to follow, later -converted to Che-, greater purposes and decisions that would take him to a higher dimension marked by his unwavering determination to fight for the true sovereignty and independence of the continent. This view seen from its historical evolution, contributes to a more complete comprehension to understand the objectives that it was proposed to achieve since it began its first journeys through regions, aggressive and suggestive, but all with identical results: an unstoppable commitment with the Latin American man and his full liberation.
\end{abstract}

Keywords: Ernesto Che Guevara -Latin America - Liberation - Sovereignty 